\title{
A medium dose of UVA1 phototherapy does not diminish vitamin $D$ level in patients with atopic dermatitis
}

\section{Fototerapia średnimi dawkami UVA1 nie zmniejsza stężenia witaminy D w surowicy chorych na atopowe zapalenie skóry}

Małgorzata Bernacka, Anna Woźniacka, Karolina Malinowska, Jarosław Bogaczewicz

Department of Dermatology and Venereology, Medical University of Lodz, Lodz, Poland

Klinika Dermatologii i Wenerologii, Uniwersytet Medyczny w Łodzi, Łódź, Polska

Dermatol Rev/Przegl Dermatol 2020, I07, |48-158

DOI: https://doi.org// 0.5 I 4/dr.2020.96358

\author{
CORRESPONDING AUTHOR/ \\ ADRES DO KORESPONDENCJI: \\ lek. Małgorzata Bernacka \\ Klinika Dermatologii \\ i Wenerologii \\ Uniwersytet Medyczny w Łodzi \\ Plac J. Hallera 1/6 \\ 90-647 Łódź, Polska \\ tel.: +48426867981 \\ e-mail: \\ malgosia.bernacka@interia.pl
}

\begin{abstract}
Introduction. Medium-dose UVA1 phototherapy is a widely used method in treatment in patients with atopic dermatitis. There are suggestions that UVA1 can decrease cutaneous production of vitamin D via photodegradation.

Objective. To determine whether a medium dose of UVA1 phototherapy decreases serum concentration of vitamin $\mathrm{D}$ in patients with atopic dermatitis.

Material and methods. The study included 21 patients with atopic dermatitis. A serum concentration of calcidiol $(25(\mathrm{OH}) \mathrm{D})$ was measured at the start and end of 20-day medium-dose UVA1 phototherapy: one exposure daily from Monday to Friday, with increasing doses of $10 \mathrm{~J} / \mathrm{cm}^{2}, 20 \mathrm{~J} / \mathrm{cm}^{2}, 30 \mathrm{~J} / \mathrm{cm}^{2}$ and $45 \mathrm{~J} / \mathrm{cm}^{2}$.

Results. Phototherapy with UVA1 significantly reduced the SCORAD index $(p<0.001)$, extent of skin lesions $(p<0.001)$ and subjective symptoms $(p<0.001)$. A serum concentration of $25(\mathrm{OH}) \mathrm{D}$ negatively correlated with the SCORAD index before UVA1 phototherapy $(r=-0.57$; $p<0.05)$. The serum concentration of $25(\mathrm{OH}) \mathrm{D}$ did not differ before and during the course of phototherapy. The recommended level of vitamin D before UVA1 phototherapy was found in $5(23.8 \%)$ patients, whereas insufficiency in $4(19 \%)$ and deficiency in $12(57.2 \%)$ patients with atopic dermatitis.

Conclusions. A medium dose of UVA1 phototherapy does not diminish the serum concentration of $25(\mathrm{OH}) \mathrm{D}$ in patients with atopic dermatitis. There is a need for further research on a larger group of individuals to confirm these findings.
\end{abstract}

\section{STRESZCZENIE}

Wprowadzenie. Fototerapia średnimi dawkami UVA1 jest powszechnie przyjętą metodą leczenia chorych na atopowe zapalenie skóry. Istnieją sugestie, że promieniowanie UVA1 może zmniejszać stężenie witaminy D w skórze wskutek fotodegradacji.

Cel pracy. Określenie, czy fototerapia średnimi dawkami UVA1 zmniejsza stężenie witaminy D w surowicy chorych na atopowe zapalenie skóry.

Materiał i metody. Badaniem objęto 21 chorych na atopowe zapalenie skóry. Oznaczono stężenie kalcydiolu $(25(\mathrm{OH}) \mathrm{D})$ w surowicy przed 
rozpoczęciem i po 20 dniach fototerapii średnimi dawkami UVA1 w schemacie obejmującym jedno naświetlanie dziennie od poniedziałku do piątku, zaczynając od dawki $10 \mathrm{~J} / \mathrm{cm}^{2}$, następnie $20 \mathrm{~J} / \mathrm{cm}^{2}$, $30 \mathrm{~J} / \mathrm{cm}^{2}$ i kontynuując dawkę $45 \mathrm{~J} / \mathrm{cm}^{2}$.

Wyniki. Fototerapia UVA1 istotnie zmniejszyła wartość wskaźnika SCORAD $(p<0,001)$, rozległość zmian skórnych $(p<0,001)$ i nasilenie objawów subiektywnych $(p<0,001)$ u chorych na atopowe zapalenie skóry. Stężenie $25(\mathrm{OH}) \mathrm{D}$ w surowicy ujemnie korelowało z wartościami wskaźnika SCORAD u chorych na atopowe zapalenie skóry przed włączeniem fototerapii UVA1 $(r=-0,57 ; p<0,05)$. Nie stwierdzono różnic w stężeniu $25(\mathrm{OH}) \mathrm{D}$ w surowicy chorych na atopowe zapalenie skóry przed zastosowaniem fototerapii UVA1 i po zakończeniu leczenia. Zalecane stężenie witaminy D przed włączeniem UVA1 fototerapii wykazano tylko u 5 (23,8\%) pacjentów, niedobór witaminy D u 4 (19\%) badanych, a ciężki niedobór witaminy D u 12 (57,2\%) chorych na atopowe zapalenie skóry.

Wnioski. Fototerapia średnimi dawkami UVA1 nie zmniejsza stężenia $25(\mathrm{OH}) \mathrm{D}$ w surowicy chorych na atopowe zapalenie skóry. Potrzebne są dalsze badania potwierdzające tę tezę, obejmujące większą grupę badaną.

Key words: atopic dermatitis, vitamin D, phototherapy, UVA.

Słowa kluczowe: atopowe zapalenie skóry, witamina D, fototerapia, UVA.

\section{INTRODUCTION}

Phototherapy with UVA1 represents a valuable method of treatment in dermatology. However, it has had a relatively short history, which began with the introduction by Plewing and Mutzhas of a high intensity UVA irradiation apparatus [1, 2]. Krutmann et al. demonstrated the effectiveness of highdose UVA1 irradiation in patients with an acute exacerbation of atopic dermatitis (AD) and noted that irradiation with high levels of UVA1 significantly reduced the serum level of eosinophil cationic protein $(\mathrm{ECP})$ in $\mathrm{AD}$ patients and that it could modulate the functions of eosinophils [3]. UVA1 (340-400 nm) is closer to visible light than UVA2 (320-340 nm), which exerts biological effects similar to those of UVB (290-320 nm). The dosage of UVA1 could be classified as low (20-40 J/ $\left.\mathrm{cm}^{2}\right)$, medium (40-80 J/ $\left.\mathrm{cm}^{2}\right)$ and high $\left(80-120 \mathrm{~J} / \mathrm{cm}^{2}\right)$ [4]. UVA1 phototherapy has been used in various diseases, including scleroderma [5, 6], sclerodermic graft-versus-host disease [7, 8], lichen sclerosus and atrophicus [9], mycosis fungoides [10,11], lymphomatoid papulosis [12], cutaneous sarcoidosis [13], AD, urticaria pigmentosa, prurigo nodularis, granuloma annulare and keratosis lichenoides chronica [14].

UVA1 exposure is associated with relatively low numbers of side effects compared to other types of phototherapy. The most frequent acute side effects being hyperpigmentation, redness, dryness and

\section{WPROWADZENIE}

Fototerapia UVA1 stanowi wartościową metodę leczenia dermatologicznego. Leczenie to ma jednak stosunkowo krótką historię, która rozpoczęła się wraz z wprowadzeniem przez Plewinga i Mutzhasa aparatu do naświetlania promieniowaniem UVA o dużym natężeniu $[1,2]$. Krutmann i wsp. wykazali skuteczność fototerapii dużymi dawkami UVA1 u pacjentów z ostrym zaostrzeniem atopowego zapalenia skóry (AZS). Zaobserwowali ponadto, że naświetlanie dużymi dawkami UVA1 istotnie zmniejsza stężenie kationowego białka eozynofilowego (eosinophil cationic protein - ECP) w surowicy pacjentów z AZS i w ten sposób może modulować funkcje eozynofilów [3]. Promieniowanie UVA1 (340$400 \mathrm{~nm}$ ) jest bliższe zakresu światła widzialnego niż promieniowanie UVA2 (320-340 nm), które wywołuje skutki biologiczne zbliżone do promieniowania UVB (290-320 nm). Dawki promieniowania UVA1 można podzielić na niskie $\left(20-40 \mathrm{~J} / \mathrm{cm}^{2}\right)$, średnie $\left(40-80 \mathrm{~J} / \mathrm{cm}^{2}\right)$ i wysokie $\left(80-120 \mathrm{~J} / \mathrm{cm}^{2}\right)$ [4]. Fototerapia UVA1 jest stosowana w leczeniu różnych chorób, takich jak twardzina układowa [5, 6], postać twardzinowa choroby przeszczep przeciwko gospodarzowi [7, 8], liszaj twardzinowy i zanikowy [9], ziarniniak grzybiasty [10, 11], lymphomatoid papulosis [12], sarkoidoza skórna [13], AZS, pokrzywka barwnikowa, świerzbiączka guzkowa, ziarniniak obrączkowaty i rogowacenie liszajowate przewlekłe [14]. 
pruritus. Chronic side effects include photoaging and possible photocarcinogenesis [15]. However, the role of UVA in the development of melanoma is ambiguous. There is a report of a patient with urticaria pigmentosa, in whom melanoma developed after intensive UVA1 phototherapy and PUVAbath therapy [16]. Moreover Westerdahl et al. report a relationship between the use of sunlamp/ sunbeds, which emit mainly UVA, and the development of melanoma [17].

Godar et al. hypothesize a relationship between increased UVA exposure, decreased cutaneous vitamin D levels and increasing incidence of melanoma [18]. They revealed that UVA passes easily through the windows, resulting in photodegradation of vitamin $\mathrm{D}$ in people working indoors. On the other hand, incident UVB is filtered out by most windows, thus lowering vitamin D synthesis in human skin [18]. In addition, Kimeswenger et al. showed that UVA1 might contribute to development of melanoma via inhibition of the repair of UVB-induced cyclobutane pyrimidine dimers (CPD) in human melanocytes [19]. Similarly, Feldmeyer et al. report that UVA1 therapy alone induced a reduction in serum $25(\mathrm{OH}) \mathrm{D}$ concentrations [20]. However, the study was limited by the fact that the study group comprised patients with a wide variety of skin diseases, and these could have had a variety of influences on the findings: the group included 13 patients with morphea, 4 with scleroderma, and individual cases of lichen sclerosus et atrophicus, atrophoderma idiopathica et progressiva, cutaneous verrucous lupus erythematosus, melanosis circumscripta, oid-oid disease, and telangiectasia macularis eruptiva perstans [20].

\section{OBJECTIVE}

As UVA1 plays such a pivotal role in dermatological treatment, the aim of the present study was to determine whether medium-dose UVA1 phototherapy decreases the serum concentration of vitamin $\mathrm{D}$ in patients with $\mathrm{AD}$.

\section{MATERIAL AND METHODS}

The study included 21 patients with AD, 13 females and 8 males, at the age of $32.81 \pm 11.91$ years. A diagnosis of $\mathrm{AD}$ was based on the criteria proposed by Hanifin and Rajka [21]. The duration of AD was $24.95 \pm 12.8$ years. The SCORAD index was used in the assessment of $\mathrm{AD}$ as well as its spread and subjective symptoms [22].

All participants gave their informed consent prior to the study. The project was approved by the local Ethics Committee (RNN/16/14/KE).
Naświetlanie promieniowaniem UVA1 wywołuje stosunkowo niewielką liczbę działań niepożądanych $\mathrm{w}$ porównaniu z innymi rodzajami fototerapii. Do najczęstszych ostrych działań niepożądanych należą: przebarwienia skóry, zaczerwienienie, suchość i świąd. Przewlekłe działania niepożądane obejmują fotostarzenie i potencjalnie fotokancerogenezę [15]. Rola UVA $w$ rozwoju czerniaka jest nadal niejednoznaczna. $W$ piśmiennictwie dostępny jest opis przypadku pacjenta z pokrzywką barwnikową, u którego wystąpił czerniak wskutek stosowania intensywnej fototerapii UVA1 oraz metody kąpielowej PUVA (tzw. PUVA-bath) [16]. Westerdahl i wsp. opisali zależność między wykorzystaniem lamp lub łóżek opalających, które emitują głównie promieniowanie UVA, a rozwojem czerniaka [17].

Godar i wsp. wysunęli hipotezę dotyczącą związku między wzmożoną ekspozycją na promieniowanie UVA, zmniejszonym stężeniem witaminy D w skórze i wzrostem częstości występowania czerniaka [18]. Autorzy wskazują, że promieniowanie UVA, przenikając przez szyby pomieszczeń, może powodować rozkład witaminy D, co z kolei sprzyja rozwojowi czerniaka u osób pracujących wewnątrz tych pomieszczeń. Z drugiej strony promieniowanie UVB zostaje zatrzymane przez szyby okienne, co powoduje brak syntezy witaminy D w skórze [18]. Ponadto Kimeswenger i wsp. stwierdzili, że promieniowanie UVA1 może się przyczyniać do rozwoju czerniaka poprzez hamowanie naprawy indukowanych przez UVB dimerów cyklobutanopirymidynowych (CPD) w ludzkich melanocytach [19]. Podobnie Feldmeyer i wsp. wykazali, że terapia UVA1 zmniejsza stężenia 25(OH)D w surowicy [20]. Badanie miało jednak pewne ograniczenia. Przede wszystkim obejmowało pacjentów o szerokim spektrum chorób skóry, których obecność mogła w różny sposób oddziaływać na wyniki. Do grupy włączono bowiem 13 pacjentów z twardziną ograniczoną, $4 \mathrm{z}$ twardziną układową, a także pojedynczych chorych z liszajem twardzinowym i zanikowym, atrophoderma idiopathica et progressiva, postacią skórną brodawkowatą tocznia rumieniowatego, melanozą ograniczoną, zespołem Sulzbergera-Garbego (choroba oid-oid) i mastocytozą skórną grudkowo-plamistą [20].

\section{CEL PRACY}

Ponieważ UVA1 odgrywa istotną rolę w leczeniu dermatologicznym, celem niniejszego badania było ustalenie, czy fototerapia średnimi dawkami UVA1 zmniejsza stężenie witaminy D w surowicy chorych na AZS.

\section{MATERIAŁ I METODY}

Badaniem objęto 21 chorych na AZS: 13 kobiet i 8 mężczyzn w wieku 32,81 $\pm 11,91$ roku. Rozpozna- 
Exclusion criteria comprised the use of sunbeds during the previous 6 months and during the study, the use of phototoxic or photoallergic drugs, immunosuppressants, retinoids and glucocorticosteroids, as well as the presence of pregnancy, photosensitivity, solar urticaria, epilepsy, glaucoma, cataract, and claustrophobia. The study was conducted in the Lodz region, located between $51^{\circ}$ and $52^{\circ} \mathrm{N}$ latitude, it has a cold season defined as the period between $5^{\text {th }}$ October and $5^{\text {th }}$ April, and a warm one between $6^{\text {th }}$ April and $4^{\text {th }}$ October. Eleven patients were studied during the cold season, and ten during the warm season.

The protocol for phototherapy with UVA1 comprised one irradiation session daily, on working days (from Monday to Friday) using a Medisun 24000 (Schulze \& Bohm, GmbH, Germany). The starting dose was $10 \mathrm{~J} / \mathrm{cm}^{2}$ (on the first day), which was then increased to 20,30 , and $45 \mathrm{~J} / \mathrm{cm}^{2}$ on subsequent days. Following this, the $45 \mathrm{~J} / \mathrm{cm}^{2}$ dose was continued up to 20 days of phototherapy. During the study, patients were permitted to use emollients.

Serum concentration of vitamin $\mathrm{D}$ was estimated by measurements of calcidiol $\left(25(\mathrm{OH}) \mathrm{D}_{3}\right)$, the main metabolite of vitamin D in the blood [23]. Blood was collected on two occasions: once before and once after UVA1 phototherapy. Serum vitamin D concentration was measured using electrochemiluminescence immunoassay (ECLIA) with an Elecsys 2010 automated analyser (Roche Diagnostics, Mannheim, Germany). Reagents with the following catalogue numbers 11706802001 , 11706799001, 11776576322, 10394246001, 03314847190 were obtained from Roche Diagnostics (Mannheim, Germany). Vitamin D status was estimated on the basis of serum concentration of $25(\mathrm{OH}) \mathrm{D}$ and defined as follows: deficiency $<20 \mathrm{ng} / \mathrm{ml}(<50 \mathrm{nmol} / \mathrm{l})$, insufficiency $21-29 \mathrm{ng} / \mathrm{ml}(52.5-72.5 \mathrm{nmol} / 1)$ and recommended range $30-80 \mathrm{ng} / \mathrm{ml}(72.5-200 \mathrm{nmol} / \mathrm{l})$ [24].

\section{Statistical analysis}

Statistical analysis was performed using Statistica software version 14.0 (StatSoft, Poland). As the vitamin D concentration did not display a Gaussian distribution, as indicated by the Shapiro-Wilk test, the nonparametric Wilcoxon signed-rank test was employed to compare the vitamin D level before and after UVA1 phototherapy, and the Spearman's rank correlation coefficient was used to assess correlations. In all calculations, $p<0.05$ was considered as statistically significant.

\section{RESULTS}

The SCORAD index in patients with AD before UVA1 phototherapy was 63.50 (56.00-72.00), whereas after UVA1 phototherapy it was decreased to 37.50 nie AZS ustalono na podstawie kryteriów diagnostycznych zaproponowanych przez Hanifina i Rajkę [21]. Czas trwania AZS u badanych pacjentów wynosił $24,95 \pm 12,8$ roku. Przy ocenie AZS wykorzystano wskaźnik SCORAD, a także oceniono rozległość zmian skórnych i nasilenie objawów subiektywnych [22].

Wszyscy pacjenci wyrazili świadomą zgodę na udział w badaniu. Projekt badania został zatwierdzony przez lokalną komisję bioetyczną (nr decyzji RNN/16/14/KE).

Z projektu wykluczono osoby, które korzystały z solariów w czasie 6 miesięcy poprzedzających badanie i w trakcie badania, osoby przyjmujące leki fototoksyczne i fotoalergiczne, immunosupresyjne, retinoidy, glikokortykosteroidy oraz kobiety w ciąży, osoby z nadwrażliwością na światło słoneczne, osoby chorujące na pokrzywkę słoneczną, padaczkę, jaskrę, zaćmę czy cierpiące z powodu klaustrofobii. Badanie przeprowadzono w województwie łódzkim, które jest położone pomiędzy $51^{\circ}$ a $52^{\circ}$ szerokości geograficznej północnej. Pod względem klimatycznym rok można tutaj podzielić na połowę chłodną (od 5 października do 5 kwietnia) oraz połowę ciepłą (od 6 kwietnia do 4 października). Jedenastu pacjentów badano w chłodnym, a 10 pacjentów w ciepłym półroczu.

Protokół fototerapii UVA1 obejmował pojedynczą sesję naświetlania $\mathrm{w}$ dni robocze (od poniedziałku do piątku) przy wykorzystaniu lampy Medisun 24000 (Schulze \& Böhm GmbH, Niemcy). Dawka początkowa wynosiła $10 \mathrm{~J} / \mathrm{cm}^{2}$ (w pierwszym dniu terapii). Następnie stopniowo zwiększano ją do 20, 30 i 45 J/ $\mathrm{cm}^{2} \mathrm{w}$ kolejnych dniach leczenia. Następnie dawkę $45 \mathrm{~J} / \mathrm{cm}^{2}$ kontynuowano aż do 20. dnia fototerapii. W okresie objętym badaniem dozwolone było stosowanie emolientów.

Stężenie witaminy D w surowicy określano na podstawie oznaczenia kalcydiolu $\left(25(\mathrm{OH}) \mathrm{D}_{3}\right)$, głównego metabolitu witaminy D, we krwi [23]. Próbki krwi pobierano dwukrotnie: przed rozpoczęciem fototerapii UVA1 i po jej zakończeniu. Stężenie witaminy D w surowicy oznaczano za pomocą testu immunologicznego wykorzystującego metodę elektrochemiluminescencji (ECLIA) przy użyciu automatycznego analizatora Elecsys 2010 (Roche Diagnostic, Mannheim, Niemcy). W Roche Diagnostic (Mannheim, Niemcy) pozyskano odczynniki o numerach katalogowych 11706802001, 11706799001, 11776576322, 10394246001 i 03314847190. Poziom witaminy D oceniano na podstawie stężenia 25(OH)D w surowicy i klasyfikowano w następujący sposób: ciężki niedobór $<20 \mathrm{ng} / \mathrm{ml}(<50 \mathrm{nmol} / \mathrm{l})$, niedobór 21-29 ng/ml (52,5-72,5 nmol/1) i zalecany zakres stężeń 30-80 ng/ml (72,5-200 nmol/1) [24].

\section{Analiza statystyczna}

Analizę statystyczną przeprowadzono przy użyciu oprogramowania Statistica w wersji 14.0 (Stat- 
(26.50-41.00). Before UVA1 phototherapy the extent of skin lesions in AD patients was 35.00\% (15.00$60.00 \%)$ and after UVA1 phototherapy it was $15.00 \%$ (9.00-29.00\%). The number of subjective symptoms in patients with AD before UVA1 phototherapy was 14.00 (10.00-20.00) and after UVA1 phototherapy it was 5.00 (3.00-10.00). The serum concentration of $25(\mathrm{OH}) \mathrm{D}$ in AD patients before UVA1 phototherapy was $13.57(5.28-25.76) \mathrm{ng} / \mathrm{ml}$ and after phototherapy it was $13.70(6.65-30.97) \mathrm{ng} / \mathrm{ml}$.

Comparison of selected parameters in patients with AD before and after phototherapy is shown in table 1 .

The recommended level of vitamin D before UVA1 phototherapy was found in $5(23.8 \%)$ patients, whereas $4(19 \%)$ patients were found to be insufficient and $12(57.2 \%)$ deficient. The recommended level of vitamin D after UVA1 phototherapy was found in $6(28.57 \%)$ patients, whereas 2 patients were found to have an insufficient (9.52\%) and 13 (61.9\%) deficient level.

UVA1 phototherapy resulted in a significant decrease in the SCORAD index (fig. 1) and a significant decrease in the extent of skin lesions in patients with AD (fig. 2). UVA1 phototherapy resulted in a significant decrease in the subjective symptoms observed in AD patients (fig. 3).

Serum concentration of $25(\mathrm{OH}) \mathrm{D}$ did not differ in AD patients before and after phototherapy with UVA1 (fig. 4).

The serum concentration of $25(\mathrm{OH}) \mathrm{D}$ negatively correlated with the SCORAD index in patients with atopic dermatitis before UVA1 phototherapy ( $r=$ $-0.57 ; p<0.05)$ (fig. 5).

\section{DISCUSSION}

UVA1 is a common treatment in patients with $\mathrm{AD}$ and its effectiveness is comparable to UVB-NB [25]. Our results confirm its effectiveness as UVA1 effectively reduced the SCORAD index, extent of skin lesions and subjective symptoms. The mechanisms soft, Polska). Ponieważ stężenie witaminy D nie było zgodne z rozkładem Gaussa, co zweryfikowano testem Shapiro-Wilka, do porównania stężenia witaminy D przed fototerapią UVA1 i po fototerapii wykorzystano nieparametryczny test rang Wilcoxona. Ocenę korelacji przeprowadzono za pomocą współczynnika korelacji rang Spearmana. We wszystkich obliczeniach jako poziom istotności statystycznej przyjęto wartość $p<0,05$.

\section{WYNIKI}

Wskaźnik SCORAD u pacjentów z AZS przed zastosowaniem fototerapii UVA1 wynosił 63,50 (56,00$72,00)$, natomiast po fototerapii UVA1 zmniejszył się do 37,50 (26,50-41,00). Rozległość zmian skórnych $\mathrm{u}$ chorych na AZS przed wdrożeniem fototerapii UVA1 wyniosła $35,00 \%(15,00-60,00 \%)$, a po leczeniu zmniejszyła się do 15,00\% (9,00-29,00\%). Nasilenie objawów subiektywnych u pacjentów z AZS przed fototerapią UVA1 wynosiło $14,00(10,00-20,00)$, a po fototerapii 5,00 (3,00-10,00). Stężenie $25(\mathrm{OH}) \mathrm{D}$ w surowicy chorych na AZS wyniosło 13,57 (5,28-25,76) $\mathrm{ng} / \mathrm{ml}$ przed zastosowaniem fototerapii UVA1, a $13,70(6,65-30,97) \mathrm{ng} / \mathrm{ml}$ po jej zakończeniu.

Porównanie wybranych parametrów u chorych na AZS przed fototerapią i po jej zakończeniu przedstawiono w tabeli 1 .

Prawidłowe stężenie witaminy D przed fototerapią UVA1 stwierdzono u $5(23,8 \%)$ pacjentów. U 4 (19\%) pacjentów występował niedobór, natomiast u 12 (57,2\%) ciężki niedobór. Zalecane stężenie witaminy D po zastosowaniu fototerapii UVA1 wykazano u 6 (28,57\%) pacjentów, natomiast u $2(9,52 \%)$ pacjentów występował niedobór, a u 13 (61,9\%) ciężki niedobór.

Fototerapia UVA1 spowodowała znaczące zmniejszenie wartości wskaźnika SCORAD u pacjentów z AZS (ryc. 1) i istotnie zmniejszyła rozległość zmian skórnych (ryc. 2). Zastosowanie fototerapii UVA1 istotnie zredukowało objawy subiektywne obserwowane u chorych na AZS (ryc. 3).

Table I. Comparison of selected parameters in patients with atopic dermatitis before and after UVAI phototherapy. Results are expressed as median, lower ( $25^{\text {th }}$ centile) and upper ( $75^{\text {th }}$ centile) quartiles

Tabela I. Porównanie wybranych parametrów u pacjentów z atopowym zapaleniem skóry przed fototerapią UVAI i po jej zakończeniu. Uzyskane wyniki są wyrażone jako mediana, kwartyl dolny (25. centyl) i kwartyl górny (75. centyl)

\begin{tabular}{|c|c|c|}
\hline \multirow[t]{2}{*}{ Variable/Zmienna } & \multicolumn{2}{|c|}{ Patients with atopic dermatitis/Chorzy na atopowe zapalenie skóry } \\
\hline & Before UVAI/Przed UVAI & After UVAI/Po UVAI \\
\hline SCORAD/SCORAD & $63.50(56.00-72.00)$ & $37.50(26.50-41.00)$ \\
\hline $\begin{array}{l}\text { Extent of skin lesions (\%)/Rozległość zmian } \\
\text { skórnych (\%) }\end{array}$ & $35.00(15.00-60.00)$ & $15.00(9.00-29.00)$ \\
\hline Subjective symptoms/Objawy subiektywne & $14.00(10.00-20.00)$ & $5.00(3.00-10.00)$ \\
\hline $25(\mathrm{OH}) \mathrm{D}[\mathrm{ng} / \mathrm{ml}] / 25(\mathrm{OH}) \mathrm{D}[\mathrm{ng} / \mathrm{ml}]$ & $13.57(5.28-25.76)$ & $13.70(6.65-30.97)$ \\
\hline
\end{tabular}




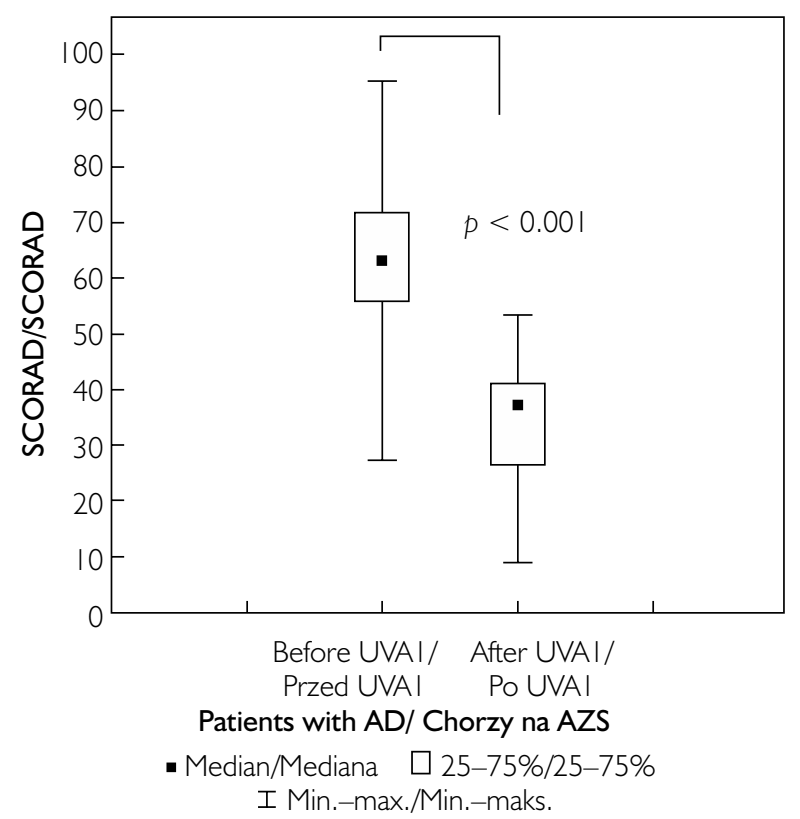

Figure I. SCORAD index was decreased in patients with atopic dermatitis (AD) undergoing UVAI phototherapy

Rycina I. Zmniejszenie wartości wskaźnika SCORAD u pacjentów $z$ atopowym zapaleniem skóry (AZS) poddanych fototerapii UVAI

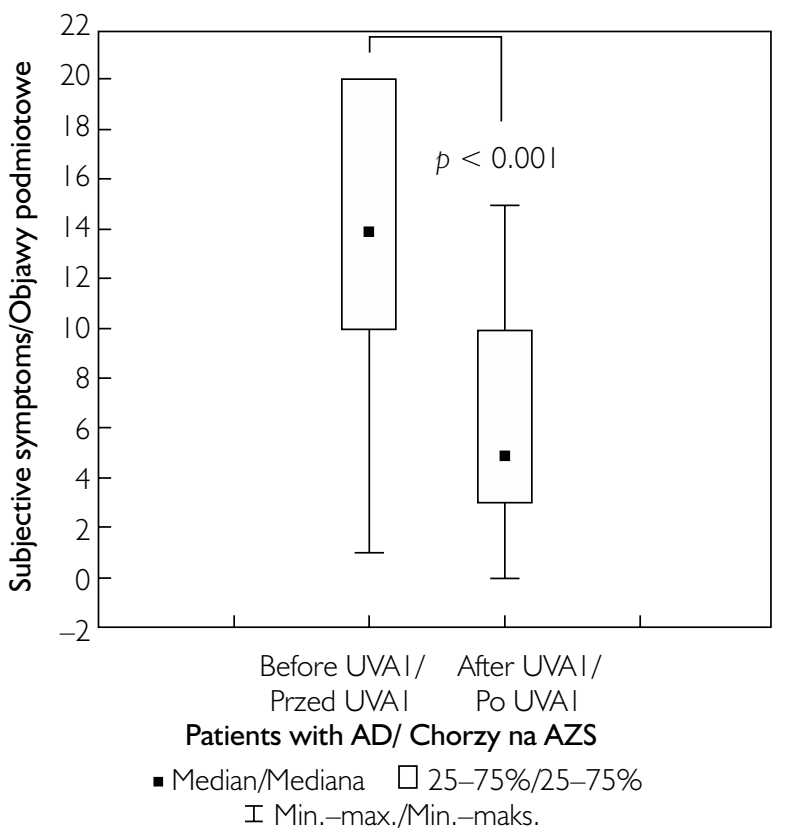

Figure 3. Subjective symptoms were decreased in patients with atopic dermatitis (AD) undergoing UVAI phototherapy

Rycina 3. Zmniejszenie objawów podmiotowych u pacjentów z atopowym zapaleniem skóry (AZS) poddanych fototerapii UVAI

underlying the biological activity of UVA1 irradiation in the skin are based around several molecular pathways: UVA1 has been found to induce formation of thymine dimmers [26, 27], increase lipid peroxidation via reactive oxygen species (ROS) generation

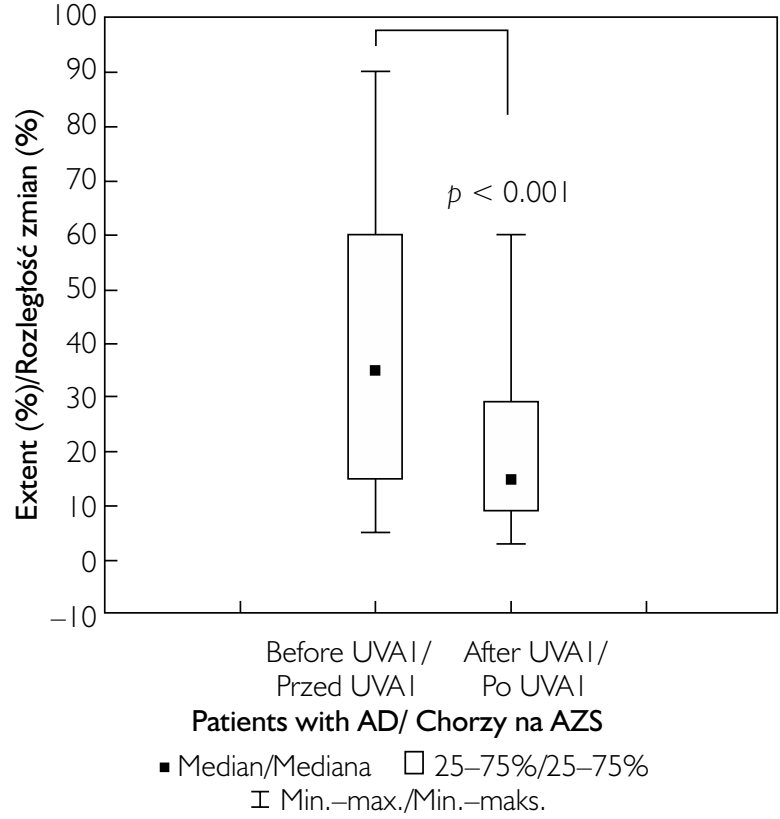

Figure 2. Extent of skin lesions was decreased in patients with atopic dermatitis (AD) undergoing UVAI phototherapy

Rycina 2. Zmniejszenie rozległości zmian skórnych u pacjentów z atopowym zapaleniem skóry (AZS) poddanych fototerapii UVAI

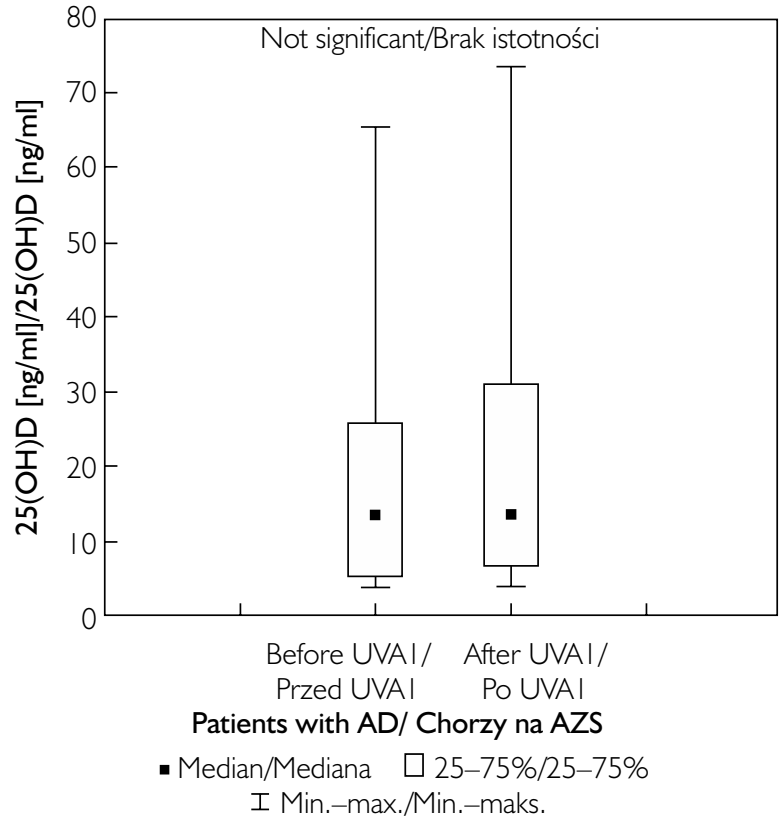

Figure 4. No difference in serum concentration of $25(\mathrm{OH}) \mathrm{D}$ was observed in atopic dermatitis (AD) patients before and after UVAI phototherapy

Rycina 4. Brak różnic pod względem stężenia 25(OH)D w surowicy pacjentów $z$ atopowym zapaleniem skóry (AZS) przed zastosowaniem i po zastosowaniu fototerapii UVAI

Nie stwierdzono różnic w stężeniu $25(\mathrm{OH}) \mathrm{D}$ w surowicy chorych na AZS przed zastosowaniem fototerapii UVA1 i po jej zakończeniu (ryc. 4).

Wykazano ujemną korelację pomiędzy stężeniem $25(\mathrm{OH}) \mathrm{D}$ w surowicy a wartością wskaźnika 


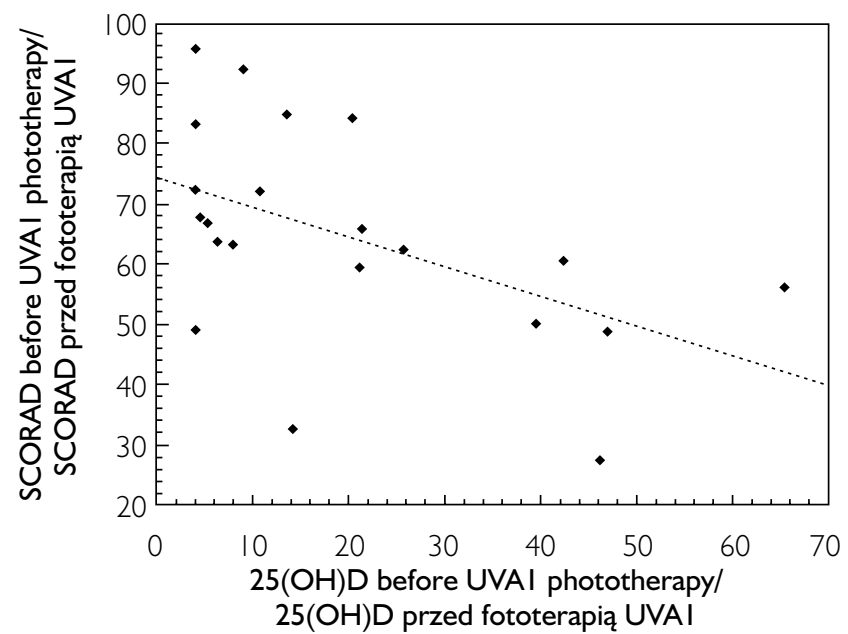

Figure 5. A negative correlation between serum concentration of 25(OH)D and SCORAD index in patients with atopic dermatitis (AD) before UVAI phototherapy $(r=-0.57 ; p<0.05)$

Rycina 5. Ujemna korelacja między stężeniem 25(OH)D w surowicy a wskaźnikiem SCORAD u pacjentów z atopowym zapaleniem skóry (AZS) przed fototerapią UVAI $(r=-0,57 ; p<0,05)$

[28], inhibit the fibrosing process by downregulating the expression of TGF- $\beta$ /Smad proteins [29], induce neovascularisation [30], and decrease tumor necrosis factor- $\alpha$ (TNF- $\alpha$ ) concentration [31].

UVA1 also acts on immune cells as it has been found to decrease dermal Langerhans cell numbers, activate eosinophils and CD4 cell and increase CD8+ lymphocytes in patients with AD [32]. UVA1 was found to downregulate Bcl-2 expression in patients with $\mathrm{AD}$ and cutaneous manifestation of cutaneous T-cell lymphoma (CTCL) [33]. In addition, the ability of UVA1 to penetrate the skin could result in more prominent changes occurring in the basal layer than in the upper layer of the epidermis [26]. UVA1 is known to induce ROS production $[34,35]$ and accelerate the photodegradation of vitamin $\mathrm{D}_{3}$ [36], and vitamin $\mathrm{D}$ deficiency may be a factor in carcinogenesis [37].

UVA1 therapy has also been found to induce a reduction in serum $25(\mathrm{OH}) \mathrm{D}$ concentration, in contrast, UVB-NB and UVA/UVB-NB, therapy were found to increase $25(\mathrm{OH}) \mathrm{D}$ levels in patients with various inflammatory skin diseases [20]. The decline of vitamin D synthesis associated with UVA1 phototherapy could be attributed to its sensitivity to photodegradation: UV wavelengths below $315 \mathrm{~nm}$ are believed to be required for vitamin D synthesis, while wavelengths as long as $330 \mathrm{~nm}$ decrease it [38]. This phenomenon can be probably responsible for the degradation of vitamin $\mathrm{D}$ during the late fall and winter since in the cold season when the solar zenith angle is lower, the radiation must travel a longer distance in the atmosphere [36]. Together with various other factors such as the skin phototype, age, clothing and use of sunscreens, a number of environmental factors such as the concentration of ozone in the atmosphere, the presence of clouds and longitudinal location, as
SCORAD u chorych na AZS przed fototerapią UVA1 $(r=-0,57 ; p<0,05)$ (ryc. 5).

\section{OMÓWIENIE}

UVA1 jest powszechnie stosowaną metodą leczenia chorych na AZS, a skuteczność naświetlań UVA1 jest porównywalna z UVB-NB [25]. Uzyskane przez nas wyniki potwierdzają skuteczność fototerapii UVA1 wyrażoną zmniejszeniem wartości wskaźnika SCORAD, ograniczeniem rozległości zmian skórnych i zmniejszeniem nasilenia objawów subiektywnych. Mechanizmy leżące u podstaw aktywności biologicznej promieniowania UVA1 w skórze opierają się na kilku szlakach molekularnych. Wykazano, że UVA1 indukuje powstawanie dimerów tyminy [26, 27], nasila peroksydację lipidów poprzez generowanie reaktywnych form tlenu (reactive oxygen species - ROS) [28], hamuje proces włóknienia poprzez obniżenie ekspresji białek TGF- $\beta /$ Smad [2], pobudza proces neowaskularyzacji [30] i zmniejsza stężenie czynnika martwicy nowotworów $\alpha$ (tumor necrosis factor- $\alpha$ - TNF- $\alpha$ ) [31].

UVA1 oddziałuje również na komórki układu odpornościowego. Zaobserwowano, że UVA1 zmniejsza liczbę komórek Langerhansa w skórze, aktywuje eozynofile i komórki CD4 oraz zwiększa poziom limfocytów CD8+ u pacjentów z AZS [32]. Wykazano, że UVA1 obniża ekspresję Bcl-2 u pacjentów z AZS i postacią skórną chłoniaka z komórek T (CTCL) [33]. Ponadto zdolność UVA1 do wnikania w skórę może wywoływać bardziej nasilone zmiany w warstwie podstawnej niż w górnej warstwie naskórka [26]. Potwierdzono, że UVA1 indukuje wytwarzanie ROS $[34,35]$ i przyspiesza fotodegradację witaminy $\mathrm{D}_{3}$ 
well as time of day, all influence cutaneous production of vitamin D [39].

Regarding UVA1, Feldmeyer et al. observed a decrease in the serum vitamin D level after UVA1 phototherapy, which they attribute the absorption of UVA1 and UVB-NB by vitamin D to [20]. In our study we did not find any differences in the serum level of vitamin D before and after UVA1 phototherapy. Both recommended, and deficient and insufficient levels of vitamin $\mathrm{D}$ were similar before and after UVA1 phototherapy. There are studies that demonstrate significantly lower 25-hydroxy vitamin $\mathrm{D}_{3}$ levels in patients with AD and a negative correlation between SCORAD and the serum vitamin $\mathrm{D}_{3}$ level $[40,41]$. Accordingly, our study reveals a negative correlation between serum concentration of 25(OH)D and SCORAD index in patients with AD before UVA1 phototherapy. It has been hypothesized that vitamin $\mathrm{D}_{3}$ deficiency is an important factor in pathogenesis of $\mathrm{AD}$, although this is debatable [42]. Sánchez-Armendáriz et al. report that supplementation with $5000 \mathrm{IU} /$ day of oral vitamin $\mathrm{D}_{3}$ has positive effects in patients with AD [43].

The biological activity of vitamin D is not limited to calcium and phosphorous homeostasis and bone metabolism [44]. Vitamin D is involved in cell differentiation, cell growth, immunomodulation, control of other hormonal systems [45] and regulation of gene transcription through VDR receptors [46]. There are reports stating that supplementation with vitamin D brings beneficial effects in many autoimmune or immune-mediated diseases, such as insulin-dependent diabetes mellitus [47], rheumatoid arthritis [48], inflammatory bowel disease [49] and AD [43]. Vitamin $\mathrm{D}_{3}$ decreases the allergic phenotype of circulating dendritic cells in children with AD [50] and stimulates innate immunity through increased expression of antimicrobial peptides, which play a crucial role in preventing skin infections $[51,52]$. Vitamin D also normalizes cytokine serum levels, such as interleukin (IL) 2, IL-4, IL-6, interferon- $\gamma$ (IFN- $\gamma$ ) in patients with AD [53].

\section{CONCLUSIONS}

Considering the key role played by vitamin $\mathrm{D}$ in the skin, it is important to know whether UVA1 phototherapy is safe for maintaining vitamin D status. Our findings suggest that in daily clinical practice, medium-dose UVA1 phototherapy does not diminish the serum concentration of $25(\mathrm{OH}) \mathrm{D}$ in patients with AD. However, our study has several limitations. Only a small group of patients with AD were examined and we cannot rule out the possible effects of UVA1 on vitamin $\mathrm{D}$ in different skin diseases. Therefore,
[36], przy czym niedobór witaminy D może stanowić czynnik kancerogenny [37].

W badaniach wykazano również, że terapia UVA1 zmniejsza stężenie $25 \mathrm{OH}(\mathrm{D})$ w surowicy, podczas gdy naświetlania UVB-NB i UVA/UVB-NB zwiększają stężenie $25 \mathrm{OH}(\mathrm{D}) \mathrm{u}$ pacjentów z różnymi chorobami zapalnymi skóry [20]. Zmniejszenie syntezy witaminy D związane $\mathrm{z}$ fototerapią UVA1 można wyjaśnić podatnością tej witaminy na proces fotodegradacji: uważa się, że promieniowanie UV o długości fali poniżej $315 \mathrm{~nm}$ jest niezbędne do syntezy witaminy $\mathrm{D}$, natomiast przy długości fali rzędu $330 \mathrm{~nm}$ następuje ograniczenie syntezy tej witaminy [38]. Zjawisko to może prawdopodobnie odpowiadać za rozkład witaminy D późną jesienią i zimą, ponieważ w chłodnym półroczu, kiedy kąt zenitalny jest mniejszy, promieniowanie musi przebyć większą odległość w atmosferze [36]. Oprócz innych czynników, takich jak fototyp skóry, wiek, rodzaj odzieży i stosowanej ochrony przeciwsłonecznej, na wytwarzanie witaminy D w skórze wpływa szereg czynników środowiskowych, m.in. stężenie ozonu w atmosferze, obecność chmur, długość geograficzna, a także pora dnia [39].

Jeśli chodzi o zastosowanie promieniowania UVA1 - Feldmeyer i wsp. zaobserwowali zmniejszenie stężenia witaminy D w surowicy po fototerapii UVA1. Jako przyczynę tego zjawiska podali absorpcje UVA1 i UVB-NB przez witaminę D [20]. Nie stwierdzono znaczących różnic w zakresie stężenia witaminy $\mathrm{D}$ u pacjentów przed zastosowaniem fototerapii UVA1 i po jej zakończeniu. Liczba osób, u których stężenie witaminy D było zgodne z zalecanym, a także osób z niedoborem i ciężkim niedoborem tej witaminy, była zbliżona przed rozpoczęciem fototerapii UVA1 oraz po jej zakończeniu. W piśmiennictwie dostępne są prace, w których wykazano istotnie niższe stężenie 25-hydroksywitaminy $\mathrm{D}_{3}$ u pacjentów z AZS oraz ujemną korelację między wskaźnikiem SCORAD a stężeniem witaminy $\mathrm{D}_{3} \mathrm{w}$ surowicy $[40,41]$. Także w przeprowadzonym przez nas badaniu stwierdzono ujemną korelację między stężeniem 25(OH)D w surowicy a wartością wskaźnika SCORAD u pacjentów z AZS przed zastosowaniem fototerapii UVA1. W literaturze można znaleźć hipotezę, według której niedobór witaminy $\mathrm{D}_{3}$ stanowi istotny czynnik w patogenezie AZS. Należy jednak zaznaczyć, że jest to hipoteza dyskusyjna [42]. Sánchez-Armendáriz i wsp. wskazują, że doustna suplementacja witaminą $\mathrm{D}_{3}$ w dawce 5000 j.m./dobę przynosi pozytywne efekty u chorych na AZS [43].

Aktywność biologiczna witaminy D nie ogranicza się do homeostazy wapnia i fosforu oraz metabolizmu kostnego [44]. Witamina D uczestniczy w procesie różnicowania i wzrostu komórek, immunomodulacji, kontroli innych układów hormonalnych [45] 
further studies are required involving more numerous groups of patients with AD and other skin diseases, in whom UVA1 phototherapy is indicated.

\section{CONFLICT OF INTEREST}

The authors declare no conflict of interest. oraz regulacji transkrypcji genów za pośrednictwem receptorów VDR [46]. Istnieją doniesienia, że suplementacja witaminą D przynosi korzyści w wielu chorobach autoimmunologicznych lub o podłożu immunologicznym, takich jak cukrzyca insulinozależna [47], reumatoidalne zapalenie stawów [48], nieswoiste zapalenia jelit [49] i AZS [43]. Ponadto witamii na $\mathrm{D}_{3}$ zmniejsza fenotyp alergiczny krążących komórek dendrytycznych u dzieci z AZS [50] i pobudza wrodzoną odporność poprzez wzrost ekspresji peptydów przeciwdrobnoustrojowych, które odgrywają istotną rolę $\mathrm{w}$ zapobieganiu zakażeniom skórnym $[51,52]$. Witamina D normalizuje również stężenia cytokin, takich jak interleukina (IL) 2, IL-4, IL-6, interferon $\gamma(\mathrm{IFN}-\gamma)$, w surowicy pacjentów z AZS [53].

\section{WNIOSKI}

Ze względu na istotne znaczenie witaminy $\mathrm{D}$ dla skóry ważne jest ustalenie, czy fototerapia UVA1 jest bezpieczna dla utrzymania poziomu witaminy $\mathrm{D}$. Nasze wyniki wskazują, że w codziennej praktyce klinicznej fototerapia średnimi dawkami UVA1 nie zmniejsza stężenia 25(OH)D w surowicy chorych na AZS. Przeprowadzone badanie ma pewne ograniczenia. Przebadano jedynie niewielką grupę pacjentów z AZS i nie można wykluczyć potencjalnego wpływu UVA1 na witaminę D w przypadku innych chorób skóry. Z uwagi na to ograniczenie potrzebne są kolejne badania prowadzone w liczniejszych grupach pacjentów z AZS i innymi schorzeniami skóry, u których wskazana jest fototerapia UVA1.

\section{KONFLIKT INTERESÓW}

Autorzy nie zgłaszają konfliktu interesów.

\section{References}

\section{Piśmiennictwo}

1. Mutzhas M.F., Hölzle E., Hofmann C., Plewig G.: A new apparatus with high radiation energy between 320-460 nm: physical description and dermatological applications. J Invest Dermatol 1981, 76, 42-47.

2. Plewig G., Hofmann C., Braun-Falco O., Nath G., Kreitmair A.: A new apparatus for the delivery of high intensity UVA and UVA+UVB irradiation, and some dermatological applications. Br J Dermatol 1978, 98, 15-24.

3. Krutmann J., Czech W., Diepgen T., Niedner R., Kapp A., Schöpf E.: High-dose UVA1 therapy in the treatment of patients with atopic dermatitis. J Am Acad Dermatol 1992, 26, 225-230.

4. York N.R., Jacobe H.T.: UVA1 phototherapy: a review of mechanism and therapeutic application. Int J Dermatol 2010, 49, 623-630.

5. Kerscher M., Dirschka T., Volkenandt M.: Treatment of localised scleroderma by UVA1 phototherapy. Lancet 1995, 346, 1166.

6. Morita A., Kobayashi K., Isomura I., Tsuji T., Krutmann J.: Ultraviolet A1 (340-400 nm) phototherapy for scleroderma in systemic sclerosis. J Am Acad Dermatol 2000, 43, 670-674.

7. Grundmann-Kollmann M., Behrens S., Gruss C., Gottlöber P., Peter R.U., Kerscher M.: Chronic sclerodermic graft-versushost disease refractory to immunosuppressive treatment responds to UVA1 phototherapy. J Am Acad Dermatol 2000, 42, 134-136.

8. Ständer H., Schiller M., Schwarz T.: UVA1 therapy for sclerodermic graft-versus-host disease of the skin. J Am Acad Dermatol 2002, 46, 799-800. 
9. Kreuter A., Jansen T., Stücker M., Herde M., Hoffmann K., Altmeyer P., et al.: Low-dose ultraviolet-A1 phototherapy for lichen sclerosus et atrophicus. Clin Exp Dermatol 2001, 26, 30-32.

10. Zane C., Leali C., Airò P., De Panfilis G., Pinton P.C.: “High-dose” UVA1 therapy of widespread plaque-type, nodular, and erythrodermic mycosis fungoides. J Am Acad Dermatol 2001, 44, 629-633.

11. Adışen E., Tektaş V., Erduran F., Erdem Ö., Gürer M.A.: Ultraviolet a1 phototherapy in the treatment of early mycosis fungoides. Dermatology 2017, 233, 192-198.

12. Calzavara-Pinton P., Venturini M., Sala R.: Medium-dose UVA1 therapy of lymphomatoid papulosis. J Am Acad Dermatol $2005,52,530-532$.

13. Mahnke N., Medve-Koenigs K., Berneburg M., Ruzicka T., Neumann N.J.: Cutaneous sarcoidosis treated with medium dose UVA1. J Am Acad Dermatol 2004, 50, 978-979.

14. Rombold S., Lobisch K., Katzer K., Grazziotin T.C., Ring J., Eberlein B.: Efficacy of UVA1 phototherapy in 230 patients with various skin diseases. Photodermatol Photoimmunol Photomed 2008, 24, 19-23.

15. Zandi S., Kalia S., Lui H.: UVA1 phototherapy: a concise and practical review. Skin Therapy Lett 2012, 17, 1-4.

16. Wallenfang K., Stadler R.: Association between UVA1 and PUVA bath therapy and development of malignant melanoma. Hautarzt 2001, 52, 705-707.

17. Westerdahl J., Ingvar C., Måsbäck A., Jonsson N., Olsson H.: Risk of cutaneous malignant melanoma in relation to use of sunbeds: further evidence for UV-A carcinogenicity. Br J Cancer 2000, 82, 1593-1599.

18. Godar D.E., Landry R.J., Lucas A.D.: Increased UVA exposures and decreased cutaneous vitamin $\mathrm{D}(3)$ levels may be responsible for the increasing incidence of melanoma. Med Hypotheses 2009, 72, 434-443.

19. Kimeswenger S., Dingelmaier-Hovorka R., Foedinger D., Jantschitsch C.: UVA1 impairs the repair of UVB-induced DNA damage in normal human melanocytes. Exp Dermatol 2018, 27, 276-279.

20. Feldmeyer L., Shojaati G., Spanaus K.S., Navarini A., Theler B., Donghi D., et al.: Phototherapy with UVB narrowband, UVA/UVB-NB, and UVA1 differentially impacts serum 25-hydroxyvitamin-D3. J Am Acad Dermatol 2013, 69, 530-536.

21. Hanifin J.M., Rajka G.: Diagnostic features of atopic dermatitis. Acta Derm Venereol 1980, 90, 44-47.

22. Kunz B., Oranje A.P., Labrèze L., Stalder J.F., Ring J., Taïeb A.: Clinical validation and guidelines for the SCORAD index: consensus report of the European Task Force on Atopic Dermatitis. Dermatology 1997, 195, 10-19.

23. Lips P.: Which circulating level of 25-hydroxyvitamin D is appropriate? J Steroid Biochem Mol Biol 2004, 89-90, 611-614.

24. Bogaczewicz J., Sysa-Jedrzejowska A., Arkuszewska C., Zabek J., Kontny E., McCauliffe D., et al.: Vitamin D status in systemic lupus erythematosus patients and its association with selected clinical and laboratory parameters. Lupus 2012, 21, 477-484.

25. Gambichler T., Othlinghaus N., Tomi N.S., Holland-Letz T., Boms S., Skrygan M., et al.: Medium-dose ultraviolet (UV) A1 vs. narrowband UVB phototherapy in atopic eczema: a randomized crossover study. Br J Dermatol 2009, 160, 652-658.

26. Tewari A., Sarkany R.P., Young A.R.: UVA1 induces cyclobutane pyrimidine dimers but not 6-4 photoproducts in human skin in vivo. J Invest Dermatol 2012, 132, 394-400.

27. Marionnet C., Pierrard C., Golebiewski C., Bernerd F.: Diversity of biological effects induced by longwave UVA rays (UVA1) in reconstructed skin. PLoS One 2014, 9, e105263.

28. Dissemond J., Schneider L.A., Brenneisen P., B.K., Wenk J., Wlaschek M., et al.: Protective and determining factors for the overall lipid peroxidation in ultraviolet A1-irradiated fibroblasts: in vitro and in vivo investigations.Br J Dermatol 2003, 149, 341-349.

29. Gambichler T., Skrygan M., Tomi N.S., Breuksch S., Altmeyer P., Kreuter A.: Significant downregulation of transforming growth factor-beta signal transducers in human skin following ultraviolet-A1 irradiation. Br J Dermatol 2007, 156, 951-956.

30. Breuckmann F., Stuecker M., Altmeyer P., Kreuter A.: Modulation of endothelial dysfunction and apoptosis: UVA1-mediated skin improvement in systemic sclerosis. Arch Dermatol Res 2004, 296, 235-239.

31. Skov L., Hansen H., Allen M., Villadsen L., Norval M., Barker J.N., et al.: Contrasting effects of ultraviolet A1 and ultraviolet B exposure on the induction of tumour necrosis factor-alpha in human skin. Br J Dermatol 1998, 138, 216-220. Erratum in: Br J Dermatol 1998, 139, 61. Br J Dermatol 1998, 138, 928.

32. Breuckmann F., von Kobyletzki G., Avermaete A., Pieck C., Kreuter A., Brockmeyer N.H., et al.: Mononuclear cells in atopic dermatitis in vivo: immunomodulation of the cutaneous infiltrate by medium-dose UVA1 phototherapy. Eur J Med Res 2002, 7, 315-322

33. Breuckmann F., von Kobyletzki G., Avermaete A., Kreuter A., Altmeyer P.: Efficacy of ultraviolet A1 phototherapy on the expression of bcl-2 in atopic dermatitis and cutaneous T-cell lymphoma in vivo: a comparison study. Photodermatol Photoimmunol Photomed 2002, 18, 217-222.

34. Morita A., Werfel T., Stege H., Ahrens C., Karmann K., Grewe M., et al.: Evidence that singlet oxygen-induced human T helper cell apoptosis is the basic mechanism of ultraviolet-A radiation phototherapy. J Exp Med 1997, 186, 1763-1768.

35. Godar D.E.: UVA1 radiation triggers two different final apoptotic pathways. J Invest Dermatol 1999, 112, 3-12.

36. Webb A.R., Kline L., Holick M.F.: Influence of season and latitude on the cutaneous synthesis of vitamin D3: exposure to winter sunlight in Boston and Edmonton will not promote vitamin D3 synthesis in human skin. J Clin Endocrinol Metab 1988, 67, 373-378.

37. Pilz S., Kienreich K., Tomaschitz A., Ritz E., Lerchbaum E., Obermayer-Pietsch B., et al.: Vitamin D and cancer mortality: systematic review of prospective epidemiological studies. Anticancer Agents Med Chem 2013, 13, 107-117.

38. Webb A.R., DeCosta B.R., Holick M.F.: Sunlight regulates the cutaneous production of vitamin D3 by causing its photodegradation. J Clin Endocrinol Metab 1989, 68, 882-887.

39. Webb A.R.: Who, what, where and when-influences on cutaneous vitamin D synthesis. Prog Biophys Mol Biol 2006, 92, 17-25.

40. Sharma S., Kaur T., Malhotra S.K., Rai J., Chaudhari S.: Correlation of vitamin D3 levels and SCORAD index in atopic dermatits: a case control study. J Clin Diagn Res 2017, 11, WC01-WC03.

41. Dogru M.: Is vitamin D level associated with the natural course of atopic dermatitis? Allergol Immunopathol (Madr) 2018, $46,546-551$ 
42. Vestita M., Filoni A., Congedo M., Foti C., Bonamonte D.: Vitamin D and atopic dermatitis in childhood. J Immunol Res $2015,2015,257879$.

43. Sánchez-Armendáriz K., García-Gil A., Romero C.A., Contreras-Ruiz J., Karam-Orante M., Balcazar-Antonio D., et al.: Oral vitamin D3 $5000 \mathrm{IU} /$ day as an adjuvant in the treatment of atopic dermatitis: a randomized control trial. Int J Dermatol 2018, $57,1516-1520$

44. Bischoff-Ferrari H.A., Dietrich T., Orav E.J., Dawson-Hughes B.: Positive association between 25-hydroxy vitamin D levels and bone mineral density: a population-based study of younger and older adults. Am J Med 2004, 116, 634-639.

45. Dusso A.S., Brown A.J., Slatopolsky E.: Vitamin D. Am J Physiol Renal Physiol 2005, 289, F8-F28.

46. Fleet J.C., DeSmet M., Johnson R., Li Y.: Vitamin D and cancer: a review of molecular mechanisms. Biochem J 2012, $441,61-76$.

47. Gregoriou E., Mamais I., Tzanetakou I., Lavranos G., Chrysostomou S.: The effects of vitamin d supplementation in newly diagnosed type 1 diabetes patients: systematic review of randomized controlled trials. Rev Diabet Stud 2017, 14, 260-268.

48. Wen H.Y., Luo J., Li X.F., Wei D.D., Liu Y.: 1,25-dihydroxyvitamin $\mathrm{D}_{3}$ modulates $\mathrm{T}$ cell differentiation and impacts on the production of cytokines from Chinese Han patients with early rheumatoid arthritis. Immunol Res 2019, 67, 48-57.

49. Li J., Chen N., Wang D., Zhang J., Gong X.: Efficacy of vitamin D in treatment of inflammatory bowel disease: a meta-analysis. Medicine (Baltimore) 2018, 97, e12662.

50. Cristi F., Perez-Mateluna G., Vera-Kellet C., Silva-Valenzuela S., Iturriaga C., Hoyos-Bachiloglu R., et al.: Vitamin D modulates the allergic phenotype of dendritic cells in children with atopic dermatitis. Exp Dermatol 2019, 28, 308-311.

51. Gombart A.F., Borregaard N., Koeffler H.P.: Human cathelicidin antimicrobial peptide (CAMP) gene is a direct target of the vitamin D receptor and is strongly up-regulated in myeloid cells by 1,25-dihydroxyvitamin D3. FASEB J 2005, 19, $1067-1077$.

52. Baeke F., Takiishi T., Korf H., Gysemans C., Mathieu C.: Vitamin D: modulator of the immune system. Curr Opin Pharmacol 2010, 10, 482-496.

53. Di Filippo P., Scaparrotta A., Rapino D., Cingolani A., Attanasi M., Petrosino M.I., et al.: Vitamin D supplementation modulates the immune system and improves atopic dermatitis in children. Int Arch Allergy Immunol 2015, 166, 91-96.

Received: 10.06 .2019

Accepted: 15.03 .2020

Otrzymano: $10.06 .2019 \mathrm{r}$

Zaakceptowano: 15.03 .2020 r.

How to cite this article

Bernacka M., Woźniacka A., Malinowska K., Bogaczewicz J.: A medium dose of UVA1 phototherapy does not diminish vitamin D level in patients with atopic dermatitis. Dermatol Rev/Przegl Dermatol 2020, 107, 148-158. DOI: https://doi.org/10.5114/ dr.2020.96358. 